\title{
Short Communication \\ A STUDY OF DOGMATISM AS RELATED TO INTERGENERATION GAP AND GENDER DIFFERENCES IN BANGLADESH
}

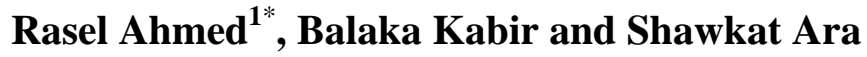 \\ Department of Psychology, Rajshahi University of Rajshahi, Rajshahi 6205, Bangladesh; \\ ${ }^{1}$ Present address: Research Fellow, Institute of Education and Research, University of Rajshahi, Rajshahi \\ 6205, Bangladesh; *Corresponding author (email: ahmedraselpsy@yahoo.com)

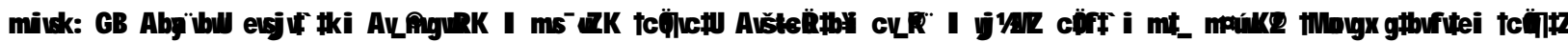

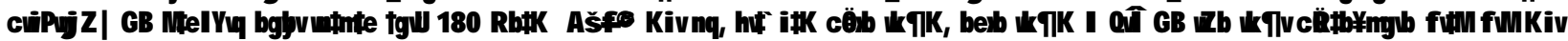

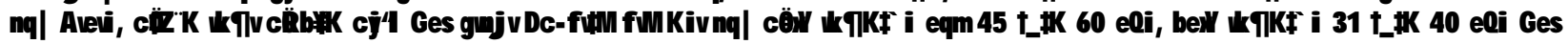

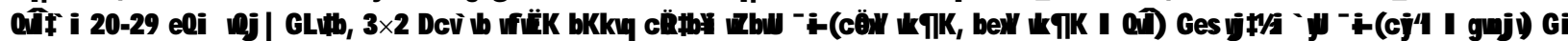

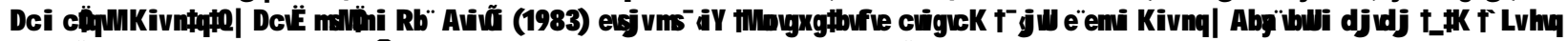

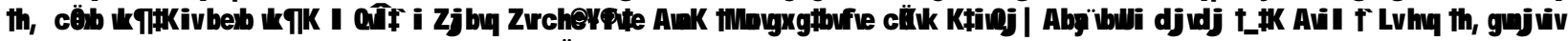

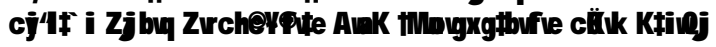

Key Words: Dogmatism, generation, gender.

The study of intergeneration gap as a function of dogmatic personality has become a significant area of research in social psychological discipline in Western (Gasset 1958; Keniston 1968; Rokeach 1968; Hanson 1976; Simonton 1983, 2005; Strauss and Howe 1991, 1997; Weir and Knight 2000; Berg et al. 2002; Hamblet and Davidson 2005; Shapiro 2005) as well as Eastern (Sinha 1972; Hasan 1974; Ara 1988, 2008; Islam 1988; Haque 2002; Rahman 2006) countries. A good number of previous researches (Davidson and Kruglov's 1953; Ara 1983; Reza 1985; Karylowski et al. 2001; Weir 2004; Rahman 2006) suggested a number of relationships among gender, masculinity, femininity and dogmatic personality. Karylowski et al. (2001) studied on gender and generation. Tbilisi (2003) observed stronger difference between generations than between genders, and at the same time stronger generational difference among the males than among the females. The younger generation is more liberal as well as more open minded in expressing their opinion.

Haque (2002) did a pioneering study on political behaviour relating to intergeneration gap, socio-political attitudes, personality variables and socio-demographic factors of older and younger political generations. The findings revealed that three younger political generations of student group were found possessing significantly more open minded on dogmatism scale as compared to three older political generations of Bangladesh. Rahman (2006) has attempted to investigate intergenerational differences relating to attitudinal variables of open mindedness-close mindedness in relation to conservatism-radicalism and demographic factors in Bangladesh. The result of the study revealed that the younger and middle-aged occupational generations exhibited less dogmatic i.e. more open minded attitudes as compared to older occupational generation. The result also revealed that the male individuals of all the three occupational generations exhibited less dogmatic i.e. more open minded as compared to their female counterpart. Most of these studies attempt to relate generational differences to dogmatic personality and gender. In developing countries very few systematic researches have been attempted on a study of dogmatism as related to intergeneration gap and gender differences in the present socio-economic and cultural context of Bangladesh. The objective of the present study was to find out the differences among three educational generations and gender differences between male and female as related to dogmatic personality in Rajshahi division of Bangladesh. Two hypotheses were formulated: (i) Older teachers possess significantly higher scores as compared to younger teachers and students on the personality variable of dogmatism, and (ii) Female individuals possess significantly higher scores on the personality variable of dogmatism as compared to their male counterparts.

The sample of the study composed of 180 respondents equally divided into older teachers (older educational generation), younger teachers (younger educational generation) and students (youngest educational generation) ( $\mathrm{N}=60$ for each group separately). Again, 
each educational generation was also sub-divided into male and female ( $\mathrm{N}=30$ for each group separately). Age of the older teachers ranged from 45 to 60 years, younger teachers ranged from 31 to 40 years and students ranged from 20 to 29 years. All the subjects (Ss) were collected from different educational institutions of Rajshahi town in Bangladesh. In the perspective of this background of sample of the present study, a total of 180 respondents were included in the sample according to our research purpose. Thus, the purposive sampling procedure was followed in sample selection.

Ara’s (1983) Bengali Version of Dogmatism Scale was used for data collection of the present study. Originally Hasan (1974) constructed the dogmatism scale. The odd even reliability of this scale obtained by Hasan was $\mathrm{r}=$ 0.71. After applying Spearman-Brown formula the coefficient obtained was 0.82. Ara modified this scale into Bengali in 1983. Her scale obtained high correlation ( $\mathrm{r}=$ 0.86) with Hasan's scale. This scale consisted of 34 items and the score ranged from 1 to 7 points or 7 to 1 points having either positive or negative characteristics. This scale contained 24 positive and 10 negative items. Individual obtained higher score was considered as dogmatic personality i.e. close-minded and individual who obtained lower score was considered as less dogmatic personality i.e. open minded. Hence the dogmatic score ranged from $34 \times 1=34$ to $34 \times 7=$ 238. The dogmatic score was determined using the formula:

Dogmatic score $=\frac{\text { Maximumpossiblescore }+ \text { Minimumpossiblescore }}{2}$

$=\frac{238+34}{2}=\frac{272}{2}=136$

Thus a subject scoring above 136 was considered as dogmatic and a subject scoring below 136 was considered as less dogmatic.

In this study Ara's (1983) Bengali Version of Dogmatism scale was administered to each of the respondents separately for the collection of data. All the respondents were the older teachers, younger teachers and students of different educational institutions in Rajshahi town. This scale was administered to the student in several groups during class period or in Hostels. On the contrary, this scale was administered on several groups of older and younger teachers at several places in different times. The respondents were directly asked to put tick mark on any option of each statement. The respondents took maximum 30 minutes to complete it. They were asked to answer each of the 34 statements. Ss were properly instructed. As soon as the data collection was completed, coding was done and the result sheet was prepared for the statistical analysis of data. The present study used $3 \times 2$ factorial design. It involves three levels of generation (older teacher, younger teacher and student) and two levels of gender (male and female).

The results on dogmatic personality have been reported in Table 1. Analysis of variance of the results showed that the main effect of generation was statistically significant $(\mathrm{F}=11.32$, $\mathrm{df}=2 / 174, \mathrm{p}<0.01)$. The main effect of gender was also statistically significant ( $\mathrm{F}=$ 11.27, $\mathrm{df}=1 / 174, \quad \mathrm{p}<0.01)$. However, two-way interaction effect was not found between generation and gender. An analysis of mean scores (Table 2) showed that regardless of gender, the older teachers (150.15) expressed significantly more dogmatism i.e. closeminded as compare to younger teachers (138.55) and students (127.23). On the other hand, students expressed significantly more open-minded in comparison to older and younger teachers. Again, mean scores (Table 2) showed that regardless of generation, female respondents (145.24) expressed significantly more dogmatism i.e. close-minded as compared to male (132.04) respondents. That means male respondents significantly expressed more open-minded in comparison to their female counterpart.

Table 1. ANOVA showing generation and gender effects on the total scores of dogmatism.

\begin{tabular}{|ccccc|}
\hline $\begin{array}{l}\text { Sources of } \\
\text { Variance }\end{array}$ & df & SS & MS & $\mathrm{F}$ \\
Generation (A) & 2 & 15756.01 & 7878.01 & $11.32^{* *}$ \\
Gender (B) & 1 & 7840.80 & 7840.80 & $11.27^{* *}$ \\
AB & 2 & 1270.63 & 635.32 & $0.91 \mathrm{~ns}$ \\
Experimental & 174 & 121043.10 & 695.65 & \\
Error & & & & \\
Total & 179 & 145910.54 \\
$*=\mathrm{P}<0.05, * *$
\end{tabular}

Table 2. Mean scores and significant mean differences for generation and gender on the total scores of dogmatism.

\begin{tabular}{|ccc|}
\hline \multirow{3}{*}{ Generation } & Older Teachers & 150.15 \\
& Younger Teachers & 138.55 \\
\multirow{2}{*}{ Gender } & Students & 127.23 \\
& Male & 132.04 \\
& Female & 145.24 \\
\hline
\end{tabular}

Various investigators (Gasset 1958; Keniston 1968; Gangarde 1969; Sinha 1972; Strauss and Howe 1997) 
mentioned that in every age, some kind of differences exist regarding dogmatic personality among the three age generations. Such conflicts among the older, younger and youngest educational generations have always been existed particularly in the society of developing countries like Bangladesh. In the present study, the result showed that older teachers possess more dogmatism i.e. closed-minded as compared to younger teachers as well as students. This finding is supported by the previous theoretical interpretation and empirical findings (Gangarde 1969; Sinha 1972; Haque 2002; Rahman 2006). Thus the first hypothesis that older teachers possess significantly higher scores as compared to younger teachers and students on the personality variable of dogmatism were confirmed by the present findings.

In this study, the differences in dogmatic personality between male and female individuals revealed that female individuals possess more dogmatism i.e. closed minded as compared to their male counterpart. This finding is supported by the previous theoretical interpretation and empirical findings (Hasan 1974; Strauss and Howe 1997; Haque 2002; Rahman 2006). Thus the second hypothesis that female individuals possess significantly higher scores as compared to their male counterpart respectively was confirmed by the present findings. On the basis of the above findings it may be concluded that the intergenerational gaps in our education sector are responsible for most of the conflict and campus violence in our country. In support of this viewpoint several researchers (Ara, 1983, Haque, 2002; Rahman, 2006) also found that conflict and campus violence are accelerated in education sector as a consequence of intergenerational gaps in our country. These generation gaps can be overcome through open and friendly discussion among the older teachers, younger teachers and students.

The present study is a novel approach for understanding and explaining educational and social behaviour of highly educated aged teachers as well as younger teachers and students scientifically, methodically and in a broader perspective of social settings. The most important feature of the study is that it is useful in the evaluation and guidance of the phenomena of social behaviour in terms of personality factors and gender differences. This feature is especially important in the current period of educational situations in Bangladesh. It is the general consensus of the administrators as well as the educationists that social behaviour should be dealt with properly for future progress of the nation with making a scientific attempt for explaining the psychological functioning of the students as well as the older teachers and younger teachers. Thus, the study makes an effort to an empirical study in the natural social setting of the educational generations and gender differences.

\section{References}

Ara S. 1983. A comparative study of socio-political attitudes of activists of India and Bangladesh. Unpublished Doctoral Dissertation, Department of Psychology, University of Allahabad, India.

Berg JS, Moore JL, Retzlaff PD and King RE. 2002. Assessment of Personality and Crew Interaction Skills in Successful Naval Aviators. J. Marketing: Theory Practice Aviat. Space Environ. Med. 73: 575-579.

Davidson HHO and Kruglov LP. 1953. Some background correlates of personality and social attitudes. J. Soc. Psychol. 38: 233-240.

Gasset OY. 1958. Man Crisis, George Allen \& Unwin, London.

Hamblet C and Davidson J. 2005. Whatever happened to the original generation, Tandem, London.

Hanson DJ. 1976. Dogmatism and Ideological orientation. Int. Rev. History Pol.l Sci. 13(2): 77-88.

Haque E. 2002. Political Behaviour: A Psychological Study of Intergenerational Differences. Unpub. PhD Thesis Dept. of Psychology, University of Rajshahi, Bangladesh.

Hasan Q. 1974. Dogmatism and Personality, Minerva Associates (Publication), Pvt. Ltd. 7-B, Lake Place: Calcutta, India.

Islam SS. 1988. Bangladesh in 1987: A spectrum of Uncertainties. Asian Survey 28: 163-171.

Karylowski JJ, Motes MA, Wallace HM, Harckom HA, Hewlett EM, Maclean LS, Parretta JL and Vaswani CL. 2001. Spontaneous gender-stereotypical categorization of trait labels and job labels. J. Social Psychol. 6(6).

Keniston K. 1968. Conservation with Kenneth Kenistan. Psychol. Today 2(6).

Plant WG, Telford CW and Thomas JA. 1965. Some personality differences between dogmatic and nondogmatic groups. J. Social Psychol. 67: 67-75.

Rahman MM. 2006. Intergenerational Comparisons on the Attitudes of Open mindedness and Close mindedness as a function of Gender and SES. Unpub. M.Sc. Thesis, Dept. of Psychology, Rajshahi University. 
Reza MS. 1985. A comparative study on radicalism of political and nonpolitical individuals in Bangladesh and India. Unpub. M.Sc. Thesis, Dept. of Psychology, Rajshahi University.

Rokeach M. 1968. Beliefs Attitudes and Values. Jossey-Bass, San Francisco.

Shapiro A. 2005. Revisiting the 'generation gap': correlates of adult child order parent discrepancies in their reports of intergenerational solidarity. Intl J. Aging Human Dev.

Simonton DK. 1983. Intergenerational transfer of individual differences in hereditary monarchs: Genes, rolemodeling, cohort, or socio-cultural effects? J. Per. Social Psychol. 44: 354-364.

Simonton DK. 2005. Presidential IQ, openness, intellectual brilliance, and leadership: estimates and correlations for 42 US chief executives. Pol. Psychol.

Sinha D. 1972. The Mughal Syndrome: A Psychological Study of Intergenerational Differences. Tata McGraw-Hill, New Delhi, India.
Strauss W and Howe N. 1991. Generations. William Morrow, New York.

Strauss W and Howe N. 1997. An Analysis of the Cycles of American History, from a generational perspective. Broadway Books.

Weir S. 2004. Intergenerational Transfers of Human Capital: Evidence on Two Types of Education Externalities Sharada. Stud. Afr. Econ. Department of Economics, University of Oxford, UK.

Weir S and Knight J. 2000. Education externalities in rural Ethiopia: Evidence from average and frontier production functions. Stud. Afr. Econ. Department of Economics, University of Oxford, UK.

Manuscript received on 10 May 2010 and revised on 7 January 2012 